\title{
The Impact of RMB Exchange Rate Fluctuation on the Export of China's Mechanical and Electrical Industry
}

\author{
$\mathrm{Li} \mathrm{Wu}$ \\ Shanghai Landward Machinery Co., Ltd. \\ Shanghai, China
}

\begin{abstract}
Exchange rate fluctuation has an important impact on import and export trade. It can affect the total volume of trade by affecting the price of trade commodity, and also affect the total volume of trade by affecting the change of national income. Electromechanical products are one of the key export commodities in China, and occupy a large proportion in export share. Therefore, studying the impact of exchange rate fluctuations on the export of mechanical and electrical products is of great practical significance. The influence on the theory of RMB exchange rate on export of review and summarize the historical changes of the RMB exchange rate policy and the historical volatility of the RMB exchange rate situation, historical development and the present situation of the export of electromechanical products, from 2006 -2016 years 10 years of monthly data of the RMB exchange rate, Chinese total exports, total exports of electromechanical products, and the mechanical and electrical industry 4 categories of key national export commodities to do empirical analysis, after empirical analysis conclusion this paper put forward relevant proposals of measures to the Chinese government and enterprises when face the RMB exchange rate fluctuations.
\end{abstract}

Keywords-RMB exchange rate fluctuation; mechanical and electrical industry; export; influence

\section{INTRODUCTION}

Since the reform and opening up, China has entered the global economy and financial market system, and has formed an export-oriented development model that focuses on export. The RMB exchange rate system was implemented in 1994 as a single system based on market supply and demand, with a managed floating exchange rate system, but for a long time it was actually a fixed exchange rate system pegged to the US dollar. This has created more favorable conditions for China's manufacturing in China. After this, China's international income support continued to increase, and the expectations for RMB appreciation appeared, In July 2005, the RMB exchange rate reform was implemented a managed floating exchange rate system based on market supply and demand, Adjusted by reference to a basket of currencies, a managed floating exchange rate regime. The flexibility of exchange rates has increased. Since the exchange rate reform, the RMB exchange rate has fluctuated more frequently. This paper focuses on the impact of RMB exchange rate fluctuation on the mechanical and electrical industry of China's major export commodities

\section{BACKGROUND AND PURPOSE OF THE STUDY}

"As of March 7, 2018, the middle exchange rate of the RMB exchange rate in the inter-bank foreign exchange market was US\$1 to RMB6.3294." In 2005, the central bank announced the reform of the RMB exchange rate system, and the RMB continued to appreciate. The RMB was from 8.008 on November 9, 2005, all the way was up to the value of 6.0408 in 2014, and had a turning point in 2014. The RMB depreciated slightly between 2014 and 2016. "Fig. 1" shows the renminbi exchange rate between 2005 and 2016. The RMB exchange rate fluctuations can be described as very frequent during the ten years of exchange reform. 


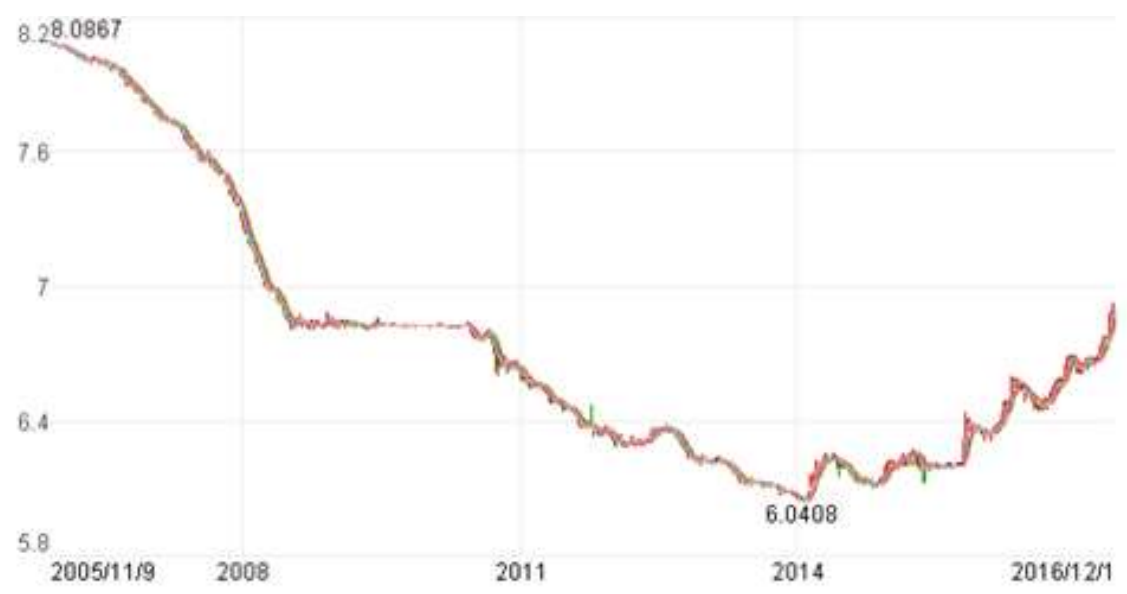

Fig. 1. 2015-2016 exchange rate chart of RMB.

The weighting of the bilateral real exchange rate for a basket of representative currencies takes into account the relative price differences between home and abroad, reflecting the fact that China's commodities have a certain degree of competitiveness in the international market, This has a very important impact on a country's economic variables such as foreign trade, investment, and industrial structure. Accompanied by the diversification of China's foreign trade, as the diversification of China's foreign trade has been strengthened, the fluctuation of the RMB exchange rate has been further intensified, and the impact of RMB exchange rate fluctuation on China's export trade has become more complicated. How to treat the RMB exchange rate fluctuation problem: On the one hand, China's import and export have experienced rapid growth for many years, In recent years, the growth rate has slowed down; on the other hand, the flexibility of the RMB exchange rate has been strengthened, and the impact of fluctuations in the RMB exchange rate and exchange rate on China's imports and exports has become more complicated.

The impact of changes in the exchange rate of the RMB is mainly reflected in the foreign trade export sector. Electromechanical products play an important role in China's foreign trade exports. Therefore, it is of great significance to study the impact of changes in the exchange rate of the RMB on the export of China's machinery and electronic industries.

Manufacturing industry is China's advantageous industry. Electromechanical products are China's key export commodities. We must implement "Made in China 2025", insist on innovation, intelligent transformation, and green development. These transformations and developments must be started from electromechanical products. Under open economic conditions, the fluctuation of a country's currency exchange rate will not only have an impact on the balance of payments, but will also have an impact on a country's trade structure and industrial structure. The development of the electromechanical industry is affected by many factors, One of the important factors is the exchange rate.

In the new situation, the fluctuation of the RMB exchange rate will have many impacts on China's export trade. For the export of mechanical and electrical products in China, the
${ }^{\text {a. }}$ Source: Netizensorganizes

fluctuation of RMB exchange rate is an opportunity and a challenge for the innovation and development of the mechanical and electrical industry. The fluctuation of RMB exchange rate will have a lasting impact on the export of mechanical and electrical industries. Under the background of China's export development and the fluctuation of RMB exchange rate, will the export of mechanical and electrical products be affected and how much will be affected? What are the effects of various products in the machinery and electronics industry? How to increase the added value of exports and avoid export risks are all issues that will be studied in depth in this article.

\section{LITERATURE REVIEW}

With regard to the related impact of exchange rate changes on exports, the mature theories are the price-coin flow system, the J-curve effect, and the Marshall-Lerner condition. This paper focuses on the following foreign classical theories and domestic scholars on the impact of RMB exchange rate on exports.

\section{A. HUME DAVID (1752) Proposed the "Price-coin Flow} System"

The main contents are as follows: A country's trade surplus causes the country's money supply to increase, which in turn causes domestic commodity prices to rise, Compared with foreign goods, the relative price of domestic goods rises, thus allowing consumers to increase purchases of foreign goods, reduce the purchase of domestic goods and make the currency (coin) lost overseas until it reaches equilibrium again. Joan Robinson proposed a theory of flexibility, which states that the balance of payments can be affected by the depreciation of the local currency through relative prices, assuming that the price of goods remains unchanged, and the elasticity of the import and export demand determines whether the devaluation of the local currency will improve the trade balance. Exchange rate changes can affect the supply and demand of a country's goods through trade and non-trade goods produced by a country and the relative price changes of domestic and foreign products, thus affecting the country' balance of payments. 


\section{B. The Marshall Condition Proposed by Marshall and Lerner}

The theory holds that the devaluation of a country's currency requires certain conditions to improve the balance of payments, that is, the sum of the exporter's demand elasticity and the elasticity of the imported goods' demand is greater than 1 , and the interplay between economic variables is not immediate, even if we Assume that Marshall's condition is established, exchange rate devaluation cannot immediately improve trade balances. On the contrary, in the early days of exchange rate devaluation, the country' $s$ trade balance may deteriorate for a period of time before it improves. This phenomenon is called the $\mathrm{J}$ curve effect.

\section{The main reasons for the $\mathrm{J}$ curve effect are:}

A. Generally speaking, the quantity and price of trade contracts signed will not change because of temporary currency devaluation, Therefore, when a country's currency depreciates, the foreign currency-priced imported goods will increase the cost of paying the converted cost currency, and vice versa.

B. Even if the trade agreement is signed after the currency devaluation, the export growth will still be subject to subjective cognition, decision-making and production cycle and other factors. Import traders may consider this to be a signal of further devaluation of the currency and further increase imports.

\section{Alexander (1953) Proposed an Absorption Analysis}

Absorption analysis uses national income and domestic absorption to analyze the impact of devaluation on trade receipts and payments. The theory holds that the devaluation of a country's currency needs to have idle resources to improve the balance of payments, so that idle resources after currency devaluation can enter the export production sector, and then can promote the increase of exports.

\section{W-Curve Effect Proposed by Paul Hallwood Et Al.}

The theory is that a devaluation of a country's currency may produce a "W-curve effect," and the depreciated trade balance of the previous period may deteriorate further, and may lead to the next currency devaluation. When continuous currency depreciation is found, the country's trade balance will not be able to eliminate the previous trade deficit and thus form a "W-curve effect."

\section{E. Multiplier Analysis}

The theory is analyzed from the perspective of the impact of national income on trade. It believes that a country's import and export is a function of the country's income. Exchange rates can affect a country's national income by changing trade multipliers. Therefore, the exchange rate can not only affect the trade balance of a country through relative price, but also affect the trade balance by affecting national income.

\section{F. Monetary Analysis}

The theory considers the monetary balance as a monetary phenomenon. Robert Mondale is the representative person who uses this analysis. Monetary analysis began to be familiar to people in the mid and late 1960s. The theory was that when a currency devaluation occurred in a country, as the country's price level increased and the actual currency balance decreased, In this case, because of the reduced expenditure of residents, the import is also reduced so that the trade balance can be improved. However, changes in the relative prices of depreciated trade and non-tradable goods will affect production adjustments and shift expenditures, which can lead to a reduction in consumption and increase in the production of trade goods, thus the trade balance is improved. On the other hand, if a country's currency appreciates, it will reduce the price level in the country, increase the actual currency balance, increase people's expenditures and increase imports, and the trade balance will deteriorate.

Domestic scholars have done a lot of research on the impact of the RMB exchange rate on China's imports and exports, but due to the different perspectives of scholars on the analysis of the problem, the selected data and measurement methods are different. And the conclusions reached are also not the same, it is concluded that Changes in the exchange rate of the renminbi have a positive or negative impact on imports and exports, but also concluded that there is no significant impact.

He Xiuqiang (2012) analyzed the impact of the real effective exchange rate of the RMB on total export volume and export commodity structure based on the data of Zhejiang Province and concluded that the appreciation of REER could significantly restrain the total export volume of Zhejiang Province and optimize the export commodity structure of Zhejiang Province. Wang Yalin (2015) studied the effect of real effective exchange rate of RMB on the export structure of mechanical and electrical products. Through analysis, the change of the real effective exchange rate of RMB has a negative effect on the export structure of the mechanical and electrical industry. This negative influence also indirectly affects the proportion of various types of merchandise exports. Zhang Dechao (2013) mainly studied the exchange rate risk aversion of an A export company from the perspective of the enterprise by using case analysis, he mainly studied the impact of exchange rate changes on export companies and How to avoid the exchange rate risk of export enterprises. Mou Dan (2013) studied the impact of the real effective exchange rate of the renminbi on China's export structure, and the influence of Exchange rate on Export structure from the Perspective of Export Commodity structure and Regional structure of Export, The conclusion is that the impact of RMB exchange rate on all industries is negative, and the exchange rate appreciation has a negative effect on the export proportion of each province. Zou Hongyuan and Luo Dawei (2014) analyzed the impact of the real effective exchange rate of the renminbi industry on the export volume of various industries in China. An Analysis of the eight main Industrial sectors in China is made according to the Industrial Classification Standards of the Customs. The results show that there are significant differences between the real effective exchange rate level and the change of the real effective exchange rate. Pan Hongyu (2006) studied that the fluctuation of RMB bilateral exchange rate does not affect Japan' exports in the long run, but there is a significant impact in the short-term. An Hui and Huang Wanyang (2009) studied the relationship between China's imports and exports of Japan and the United States and the fluctuation of the bilateral 
exchange rate of the RMB. The results show that the United States has significant effects on Japan' import and export income, price and exchange rate fluctuations. Dai Zuxiang (1997) studied China's data from 1981-1995 and concluded that China's import and export demand price elasticity satisfies the Marshall-Lernaer condition. Therefore, devaluation of the RMB exchange rate can improve the balance of China's import and export trade.

\section{HistoricAl DEVElOPMENT AND PRESENT SitUATION CHINA' MECHANICAL AND ElECTRICAL PRODUCTS EXPORT}

\section{A. Export Policy and Scale Change of Mechanical and Electrical Products in China}

Since the reform and opening up, China's foreign trade has been greatly developed. In 2016, according to the latest statistics of the General Administration of Customs, the import and export volume of goods in China fell by about $6 \%$ compared with 2015, and the trade surplus was US\$509.963 billion. Among them, exports of electromechanical products accounted for the largest proportion of China's export trade, accounting for almost $60 \%$ of China's export trade.

However, with the development of exports, it also faces the problems of unstable external demand and increased trade friction. Therefore, it is very important to change the export structure and increase export competitiveness. In the 2015 government report, the "Made in China 2025" is proposed.

By the end of 2005, China's total exports of mechanical and electrical products reached US $\$ 435.901$ billion, which was far higher than the target plan's export. In terms of export quality, the export volume of high-tech mechanical and electrical products exceeded $50 \%$. In general, the development of mechanical and electrical products in China during this period was very rapid, and the export enterprises of domestic machinery and electronic products were preliminary but developed rapidly.

By the end of 2010, China's total export of mechanical and electrical products doubled on a 2005 basis, Up to $\$ 954.866$ billion; high-tech products accounted for $51.3 \%$ of mechanical and electrical products, $3 \%$ for Africa, and $5.55 \%$ for Latin America. In terms of main body of export market, the number of enterprises exporting more than 100 million US dollars of mechanical and electrical products increased from 531 in 2005 to 1220 in 2010, while private enterprises with high-tech exports reached $9.2 \%$.

2015 is the last year of the "12th Five-Year Plan". From the data of a few years ago, the growth rate of all kinds of mechanical and electrical products has dropped to the single digits, and the export of electromechanical products has slowed down in quantity. On the one hand, under the influence of policy, and on the other hand, by external adverse factors, based on the actual situation at home and abroad, it is urgent to optimize the export structure of China's electromechanical products and enhance the competitiveness of domestic electromechanical enterprises.

\section{B. Analysis on the Total Export Quantity of China's Mechanical and Electrical Products and the Whole Country's Export}

TABLE I. TABLE OF CHANGES IN EXPORT VOLUME OF CHINA'S ELECTROMECHANICAL INDUSTRY FROM 2007 TO 2016

Unit: BILlion US Dollars Percentage

\begin{tabular}{|l|l|l|l|}
\hline Years & $\begin{array}{c}\text { National Export } \\
\text { Value (One } \\
\text { Hundred Million } \\
\text { U.S. Dollars) }\end{array}$ & $\begin{array}{c}\text { Total Export } \\
\text { Value of } \\
\text { Electromechan } \\
\text { ical Products } \\
\text { One Hundred } \\
\text { Million U.S. } \\
\text { (Dollars) }\end{array}$ & $\begin{array}{c}\text { The Proportion of } \\
\text { Electromechanical } \\
\text { Products Exports } \\
\text { in National Exports } \\
(\%)\end{array}$ \\
\hline 2007 & 12200.6 & 6895.92 & 56.52 \\
\hline 2008 & 14306.93 & 8249.59 & 57.66 \\
\hline 2009 & 12016.12 & 7222.15 & 60.1 \\
\hline 2010 & 15777.54 & 9422.51 & 59.72 \\
\hline 2011 & 18992.83 & 10859.54 & 57.18 \\
\hline 2012 & 20521.1 & 11793.40 & 57.47 \\
\hline 2013 & 22106.65 & 12659.20 & 57.26 \\
\hline 2014 & 23432.23 & 9961.96 & 42.51 \\
\hline 2015 & 22844.93 & 13188.95 & 57.73 \\
\hline 2016 & 20974.44 & 12303.93 & 53.70 \\
\hline & Source: Statistical Monthly of the General Administration of Customs of the People's \\
\hline & Republic of China and Statistical Yearbook of China Customs. Annual data and \\
percentages are calculated
\end{tabular}

As can be seen from Table I, from 2007 to 2016, the total export volume and the export volume of mechanical and electrical products all have a steady increase. The total value of national exports has increased from 1,220.06 billion U.S. dollars in 2007 to 2,097.444 billion U.S. dollars in 2016, almost increased doubled; the exports increase of electromechanical products almost doubled, from 689.592 billion U.S. dollars in 2007 to 1230.393 billion U.S. dollars in 2016. The export volume of mechanical and electrical products has always accounted for about $50-60 \%$ of the total export volume of the country, and the proportion is quite high. This shows that electromechanical products occupy a very important position in China's export commodities.

\section{EMPIRICAL ANALYSIS}

\section{A. The Selection of Data}

In terms of data, the monthly data of RMB exchange rate from August 2006 to August 2016, monthly data on gross national exports, monthly data of export value of electromechanical products in China, Monthly data on national exports of steel, uncalcined aluminium and aluminium, motors and generators, and automatic data processing equipment and their components for the four major categories of export products under the machinery and electrical industry. We have chosen the data for the 10 years since the exchange reform in 2005. On the one hand, because the trade data for the past ten years are relatively easy to collect, on the other hand, the exchange rate has fluctuate frequently since the exchange rate reform, and it is closer to the current national conditions in China, The research has more practical significance. A large sample of 10-year monthly data was selected for empirical analysis to make the test results more accurate and persuasive. The main sources of monthly data on the export volume of China's total export volume and the export volume of the 
country's mechanical and electrical products, steel products, uncalcined aluminium and aluminium materials, electric motors and generators, and automatic data processing equipment and their components are the monthly statistics report of the General Administration of Customs of China, China Customs Statistics Yearbook, Customs Information Network, Renminbi exchange rate data from the Bank of China website.

\section{B. The Construction of the Model}

There are many econometric models used by early scholars to study the impact of RMB exchange rate fluctuations on exports. He Xiuqiang (2012) mainly adopted a vector regression (VAR) model and constructed three VAR model analyses in the form of function; Wang Yaolin (2015) selected RMB exchange rate and the growth rate of export data of mechanical and electrical industry as variables to construct the model; Mou Dan (2013) choose the variables of exchange rate, GDP, actual monthly utilization of foreign capital and factor price ratio to build a model. Different scholars study different objects and purposes, and the adopted models are different. This article mainly refers to Wang Yalin's (2015) measurement model.

The variables explained in this paper are the export volume $\mathrm{Y}$ of the electromechanical industry and the total national export Z, As well as the four major export commodity steel products, not calcined aluminum and aluminum, the national exports of motor and generator and automatic data processing equipment and its components are E, F, G, H, respectively. Taking into account the source and consistency of data, this paper selects the statistics of China Customs General Administration from August 2006 to August 2016, and dealt with the data.

Explain variables to select monthly data of RMB exchange rate from August 2006 to August 2016 X.

Because the original data of $\mathrm{Y}, \mathrm{Z}, \mathrm{E}, \mathrm{F}, \mathrm{G}$, and $\mathrm{H}$ is too large, this paper converts the units of data $\mathrm{Y}$ and $\mathrm{Z}$ from thousands of dollars into ten billions of dollars, and obtains Y1, Z1. The units of $E$ and $H$ are converted from thousands of dollars into billions of dollars, we get E1, H1, convert the units of $\mathrm{F}, \mathrm{G}$ from thousands of dollars into one hundred millions of dollars, and get F1, G1, reference regression equation $\mathrm{Y}=\mathrm{BX}+\mathrm{A}$ and Wang Yalin (2015)'s measurement The metrological models used in this paper are as follows:

$$
\begin{aligned}
& \mathrm{Y} 1=\mathrm{C} 1+\mathrm{C} 2 * \mathrm{X}+\mathrm{u} \\
& \mathrm{Z} 1=\mathrm{C} 1+\mathrm{C} 2 * \mathrm{X}+\mathrm{U} \\
& \mathrm{E} 1=\mathrm{C} 1+\mathrm{C} 2 * \mathrm{X}+\mathrm{U} \\
& \mathrm{F} 1=\mathrm{C} 1+\mathrm{C} 2 * \mathrm{X}+\mathrm{U} \\
& \mathrm{G} 1=\mathrm{C} 1+\mathrm{C} 2 * \mathrm{X}+\mathrm{U} \\
& \mathrm{H} 1=\mathrm{C} 1+\mathrm{C} 2 * \mathrm{X}+\mathrm{U}
\end{aligned}
$$

Among them, Y1 is the monthly data of the export volume of the electromechanical industry, Z1 is monthly data of total national exports, E1, F1, G1 and H1 are the national exports of steel, non calcined aluminum and aluminum, motors and generators, and automatic data processing equipment and components, respectively. $\mathrm{C} 1$ is a constant item, $\mathrm{C} 2$ is a regression parameter, $\mathrm{X}$ is a monthly data of $\mathrm{RMB}$ exchange rate, and $u$ is a disturbance item.

After using EVIEWS software to regress the data, we will test the regression parameters and equations through $\mathrm{R} 2$, $\mathrm{T}$ test, and $\mathrm{P}$ value of $\mathrm{F}$ test to ensure the significance of the regression. The t-test and F-test mainly look at the $\mathrm{P}$ value of the test. The value is less than 0.05 , indicating that the regression result is significant and use D.W. to test the autoregressive condition of variables

\section{Empirical Analysis}

1) Sequence Stationarity Test (ADF Test): Using $\mathrm{ADF}$

\begin{tabular}{|c|c|c|c|c|c|}
\hline $\begin{array}{c}\text { Varia } \\
\text { ble }\end{array}$ & $\begin{array}{c}\text { Inspec } \\
\text { tion } \\
\text { Type }\end{array}$ & $\begin{array}{c}\text { Adf } \\
\text { Statistics }\end{array}$ & $\begin{array}{c}1 \% \\
\text { Threshold }\end{array}$ & $\begin{array}{c}5 \% \\
\text { Threshold }\end{array}$ & $\begin{array}{c}\text { Conclusi } \\
\text { on }\end{array}$ \\
\hline $\mathrm{X}$ & $(\mathrm{C}, \mathrm{T}, 1)$ & -0.222346 & -4.036983 & -3.448021 & Unstable \\
\hline Y1 & $(\mathrm{C}, \mathrm{T}, 0)$ & -4.588859 & -4.036310 & -3.447699 & Smooth \\
\hline $\mathrm{Z} 1$ & $\begin{array}{l}\text { (C,T,1 } \\
2)\end{array}$ & -0.836978 & -4.045236 & -3.451959 & Unstable \\
\hline E1 & $(\mathrm{C}, \mathrm{T}, 0)$ & -3.195097 & -4.036310 & -3.148946 & Unstable \\
\hline F1 & $(\mathrm{C}, 0,1)$ & -0.562086 & -3.486064 & -2.885863 & Unstable \\
\hline G1 & $(\mathrm{C}, \mathrm{T}, 1)$ & -2.693847 & -4.038365 & -3.448681 & Unstable \\
\hline H1 & $(\mathrm{C}, \mathrm{T}, 0)$ & -4.488802 & -4.036310 & -3.447699 & Smooth \\
\hline $\mathrm{D}(\mathrm{X})$ & $(\mathrm{C}, \mathrm{T}, 0)$ & -8.607992 & -4.036983 & -3.448021 & Smooth \\
\hline $\mathrm{D}(\mathrm{Y} 1)$ & $(\mathrm{C}, \mathrm{T}, 1)$ & -9.926541 & -4.037668 & -3.448348 & Smooth \\
\hline $\mathrm{D}(\mathrm{Z1})$ & $\begin{array}{l}\text { (C,T,1 } \\
2)\end{array}$ & -2.716177 & -4.046072 & -3.452358 & Unstable \\
\hline $\mathrm{D}(\mathrm{E} 1)$ & $(\mathrm{C}, \mathrm{T}, 0)$ & -10.47547 & -4.036938 & -3.448021 & Smooth \\
\hline $\mathrm{D}(\mathrm{F} 1)$ & $(\mathrm{C}, 0,0)$ & -18.85842 & -3.486064 & -2.885863 & Smooth \\
\hline $\mathrm{D}(\mathrm{G} 1)$ & $\begin{array}{l}\text { (C,T,1 } \\
2)\end{array}$ & -2.805639 & -4.046072 & -3.452358 & Unstable \\
\hline $\mathrm{D}(\mathrm{H} 1)$ & $\begin{array}{l}(\mathrm{C}, \mathrm{T}, 1 \\
2)\end{array}$ & -3.245856 & -4.046072 & -3.452358 & Unstable \\
\hline $\begin{array}{l}\mathrm{D}(\mathrm{X}, \\
2)\end{array}$ & $(\mathrm{C}, \mathrm{T}, 3)$ & -9.861232 & -4.039797 & -3.449365 & Smooth \\
\hline $\begin{array}{l}\mathrm{D}(\mathrm{Y} 1 \\
, \quad 2)\end{array}$ & $\begin{array}{l}\text { (C,T,1 } \\
0)\end{array}$ & -9.247210 & -4.045236 & -3.451959 & Smooth \\
\hline $\begin{array}{l}\mathrm{D}(\mathrm{Z} 1 \\
, \quad 2) \\
\end{array}$ & $\begin{array}{l}(\mathrm{C}, \mathrm{T}, 1 \\
1)\end{array}$ & -11.10985 & -4.046072 & -3.151673 & Smooth \\
\hline $\begin{array}{l}\mathrm{D}(\mathrm{E} 1 \\
, \quad 2)\end{array}$ & $(\mathrm{C}, \mathrm{T}, 2)$ & -11.07317 & -4.039075 & -3.449020 & Smooth \\
\hline $\begin{array}{l}\mathrm{D}(\mathrm{F} 1 \\
, \quad 2)\end{array}$ & $(\mathrm{C}, \mathrm{T}, 5)$ & -9.448170 & -3.489117 & -2.887190 & Smooth \\
\hline $\begin{array}{l}\mathrm{D}(\mathrm{G} 1 \\
, \quad 2)\end{array}$ & $\begin{array}{l}(\mathrm{C}, \mathrm{T}, 1 \\
1) \\
\end{array}$ & -7.708752 & -4.046072 & -3.452385 & Smooth \\
\hline $\begin{array}{l}\mathrm{D}(\mathrm{H} 1 \\
, \quad 2)\end{array}$ & $\begin{array}{l}\text { (C,T,1 } \\
1)\end{array}$ & -9.792167 & -4.046072 & -3.452358 & Smooth \\
\hline
\end{tabular}
method to verify the data of X, Y1Z1, E1, F1, G1 and H1 in the model and the stationarity of the corresponding first order difference sequence and the second order difference sequence, the test results are shown in "Table II":

TABLE II. ADF TEST RESULTS

Source: The author organizes

From the test results in Table II, we can see that the $\mathrm{X}$ statistic of the original sequence is greater than the critical value of 5\%, cannot reject the original hypothesis, that there is a unit root, so it is a non-stationary sequence, similarly Y1, H1 
is a stationary sequence, $\mathrm{Z} 1, \mathrm{E} 1, \mathrm{~F} 1, \mathrm{G} 1 \mathrm{It}$ is a non-stationary sequence; the first-order difference sequences $\mathrm{D}(\mathrm{X}), \mathrm{D}(\mathrm{Y} 1)$, $\mathrm{D}(\mathrm{E} 1), \mathrm{D}(\mathrm{F} 1)$ are stationary sequences, $\mathrm{D}(\mathrm{Z} 1), \mathrm{D}(\mathrm{G} 1), \mathrm{D}(\mathrm{H} 1)$ are non-stationary sequences; The second order difference sequences of all sequences are stationary sequences .

2) Regression analysis: The Regression Analysis of the Effect of RMB Exchange Rate on the Export of Mechanical and Electrical Products.

After the ADF test, it is concluded that the second-order differential sequences of all sequences are stationary sequences. Regression analysis considering the second-order difference data has no great economic significance. At the same time, refer to the practice of Wang Ya-lin (2015). regress the logarithm of the original data, in the economics, take the natural logarithm to do the regression, this time the regression equation is $\mathrm{LNY}=\mathrm{A} * \mathrm{LNX}+\mathrm{B}$, Simultaneous derivation on both sides, the result just coincides with the definition of elasticity: DLNY/DLNY $=(\mathrm{DY} / \mathrm{Y}) /(\mathrm{DX} / \mathrm{X})$. This article takes the logarithm of the original data $\mathrm{X}, \mathrm{Y}, \mathrm{Z}, \mathrm{E}, \mathrm{F}, \mathrm{G}, \mathrm{H}$, get LNX,LNY,LNZ,LNE,LNF,LNG,LNH, Use EVIEWS software to substitute LNY and LNX data for regression analysis. The regression equation is as follows:

\section{$\ln \mathrm{Y}=\mathrm{C} 1+\mathrm{C} 2 * \ln \mathrm{X}+\mathrm{u}$}

The results of the regression are as follows:

\begin{tabular}{|c|c|c|c|c|}
\hline \multicolumn{5}{|c|}{$\begin{array}{l}\text { Dependent Variable: } \mathrm{Y} \\
\text { Method: Least Squares } \\
\text { Date: 11/19/17 Time: 10:28 } \\
\text { Sample: } 2006 \text { M08 2016M08 } \\
\text { Included observations: } 121 \\
\mathrm{Y}=\mathrm{C}(1)+\mathrm{C}(2)^{*} \mathrm{X}\end{array}$} \\
\hline & Coefficient & Std. Error & t-Statistic & Prob. \\
\hline$C(1)$ & 23.56284 & 0.471292 & 49.99627 & 0.0000 \\
\hline $\mathrm{C}(2)$ & -2.835213 & 0.248873 & -11.39219 & 0.0000 \\
\hline R-squared & 0.521670 & \multicolumn{2}{|c|}{ Mean dependent var } & 18.19773 \\
\hline Adjusted R-squared & 0.517650 & \multicolumn{2}{|c|}{ S.D. dependent var } & 0.286069 \\
\hline S.E. of regression & 0.198679 & \multicolumn{2}{|c|}{ Akaike info criterion } & -0.377864 \\
\hline Sum squared resid & 4.697318 & \multicolumn{2}{|c|}{ Schwarz criterion } & -0.331652 \\
\hline Log likelihood & 24.86076 & \multirow{2}{*}{\multicolumn{2}{|c|}{$\begin{array}{l}\text { Hannan-Quinn criter. } \\
\text { Durbin-Watson stat }\end{array}$}} & -0.359096 \\
\hline F-statistic & 129.7820 & & & 0.564597 \\
\hline Prob(F-statistic) & 0.000000 & & & \\
\hline
\end{tabular}

\section{Fig. 2. LNY, LNX regression results.}

LNX: Logarithm of monthly exchange rate data of RMB exchange rate

LNY: Logarithm of monthly export data of mechanical and electrical products

It can be seen from "Fig. 2" that the DW value of the regression result is too small and there may be sequence related problems. Next we will test whether there is sequence correlation through residuals and time scatter plots, Using EVIEWS software to bring the data of lnYYLIN X into, Get the scatter point graph of the residual term and the time, as shown in "Fig. 3"

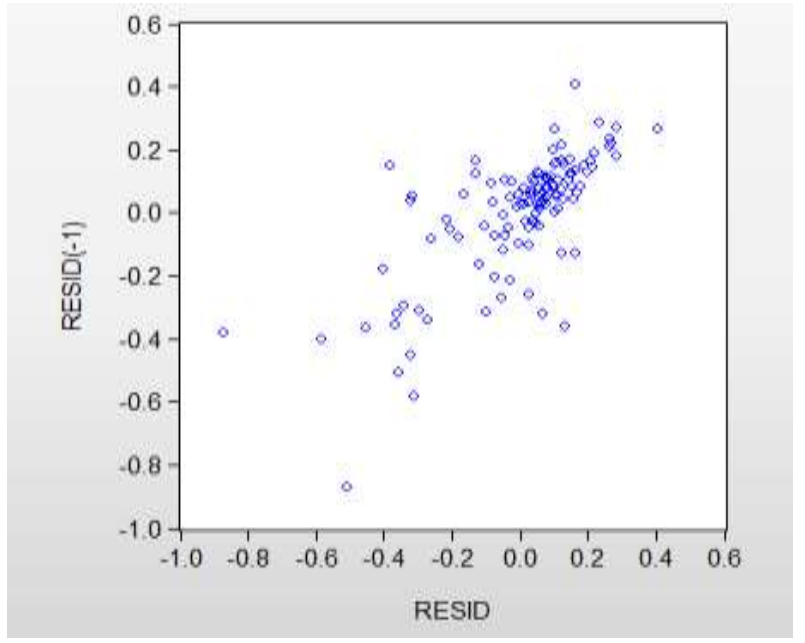

Fig. 3. LnY, $\ln \mathrm{X}$ residual term and time scatter point graph.

LnY: Logarithm of monthly export data of mechanical and electrical product

LnX: Logarithm of monthly data on nominal exchange rate of $\mathrm{RMB}$

From "Fig. 3", we can see that there is a positive sequence correlation between the sequence and the sequence; it is possible to simply judge the existence of positive sequence correlation in the mode. This paper will eliminate the sequence correlation by means of generalized difference method, and the model is modified by the generalized difference method by the EVIEWS software. The regression result obtained is shown in "Fig. 4".

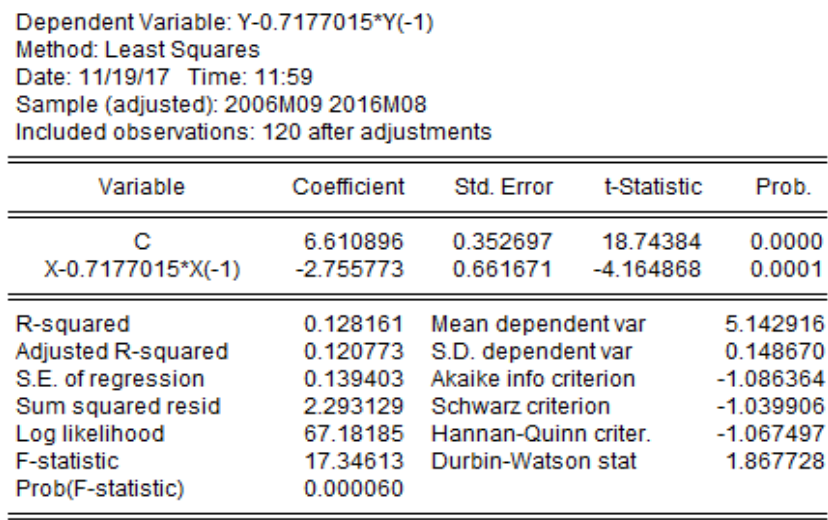

Fig. 4. The regression results after the generalized difference of LNY and LNX.

From the regression results, it can be seen that $\mathrm{DW}=1.8677$, the sequence correlation has been eliminated, and the modified model is represented as: $\mathrm{LNY}=23.4181-2.7558 \mathrm{LNX}$.

According to the regression results, The elastic value of the growth rate of China's Electromechanical industry export volume to RMB exchange rate is -2.7558 , That is, the increase of RMB exchange rate by $1 \%$ can affect the decline of export growth rate of China's machinery and electrical industry by $2.76 \%$. Conversely, when the growth rate of RMB exchange rate dropped by $1 \%$, the export growth rate of China's 
machinery and electrical industry rose by $2.76 \%$, and the relationship between the two is reversed.; the F-test $\mathrm{P}$ value and the $\mathrm{T}$-test $\mathrm{P}$ value are all less than 0.05 , and the equations and parameters are significant.

The same method is used to analyze the RMB exchange rate on the total export volume of the country and the 4 major export commodities under the electromechanical industry. From the regression results, we can conclude that the growth rate of $\mathrm{RMB}$ exchange rate and the export volume of the mechanical and electrical industry, the total export volume of the whole country, and the steel products, uncalcined aluminium and aluminium materials of the four major categories of national export commodities under the machinery and electrical industry, The growth rate of national exports of motor and generator and automatic data processing equipment and their components is inversely variable. It has a slightly different impact on the growth rate of the export volume, but in general, it's a reverse change. Therefore, through the OLS regression, the conclusion is that the growth rate of the RMB exchange rate and the growth rate of the export volume of the electromechanical industry are in a reverse change relationship. The elasticity of the two is -2.7558 , The elasticity of RMB exchange rate growth rate and total export growth rate is 3.3160 , and the elastic value of the national steel export growth rate is -2.2544 , and the elasticity value of the growth rate of export volume of uncalendered aluminum and aluminum products in china is -6.0324 , and The elasticity of the export growth rate of motor and generator in china is 3.3662, and the elastic value of the export growth rate of the national automatic data processing equipment and its components is -1.9225

\section{CONCLUSION}

\section{A. The Conclusion of the Study}

With the continuous marketization of the RMB exchange rate system in China, the export of China's whole country and of the machinery and electrical industry has been developing at a high speed. The 2014-2016 RMB devaluation was mainly due to the world economic downturn, China's economic downturn, the expectations of the Fed's rate hike, and the People's Bank of China increased in the range of exchange rate fluctuations, the RMB exchange rate was expected to continue to weaken in the future. Although the renminbi devaluation is favorable to exports, the impact in the short term is not obvious. On the contrary, in the context of the world economic downturn and the increase in China's export costs, the electromechanical industry's exports are facing more with great pressure, export enterprises in the electromechanical industry need to increase technological content of products and increase the added value of products in order to increase their global competitiveness.

By empirical analysis and regression analysis, the conclusion is that the growth rate of RMB exchange rate has a negative effect on the export growth rate of China's machinery and electrical products and its four export commodities under the industry, but the degree of impact is different. The main reasons for the analysis are: the international demand for steel is relatively stable, and the added value of automatic data processing equipment and its spare parts is high. Therefore, the export volume of these two types of commodities is less affected by fluctuations in the exchange rate of RMB, while the export of calcined aluminum and aluminum products is more affected by domestic and international price differences. At present, electric motors and generators in China are mainly made up of general electromechanical products, and their added value is not enough. These two types of commodities are greatly affected by exchange rate fluctuations.

\section{B. Mechanical and Electrical Enterprise Response Measures}

1) Reasonably avoid exchange rate risk: In the face of rapid fluctuations in the renminbi exchange rate, how should the enterprise deal with it in order to keep its owninterests unaffected? Conclusions from the previous empirical analysis, the renminbi exchange rate fluctuations will have a negative impact on the export of the electromechanical industry; how to avoid negative effects when the exchange rate appreciates, and better promote trade volume when depreciating? Mechanical and electrical enterprises should take good measures to deal with exchange rate fluctuations in order to better deal with.

a) Transaction risk control: Since the export enterprises of mechanical and electrical products often face the settlement of large amount of money, the transaction risk is quite large. Among them, the exchange rate risk has a very significant impact on the enterprises. This transaction risk can be controlled through trade financing, financial instruments etc.

b) Controlling risk through trade financing methods: Trade finance is mainly related to cooperation with banks.

Enterprises in the mechanical and electrical industry can decide on their own, trade finance can be divided into the following categories: export commercial invoice financing, Negotiation under Documentary Credit, export factoring and so on. Export commercial invoices mainly refer to the export enterprises selling goods on credit to foreign merchants, and the export enterprises transfer the loans signed by the sales contracts to the banks. Banks provide short-term financing to exporting enterprises on the basis of a certain proportion of the amount of commercial invoices; the export factoring refers to the export trade with the foreign businessmen in the way that the exporters sell on credit. After the export, the bill of goods is transferred to the factoring agent, and some or all of the funds are paid by the factoring agent, and the export enterprise obtains capital financing from it; Export credit document refers to the letter of credit opened by the bank under the issuer. After the beneficiary submits the full set of documents of the credit, the bank examines the credit document without any discrepancies, and after deducting the related handling fee, the credit is paid to the beneficiary.

When the renminbi appreciates, Foreign exchange may be collected in advance after export trade finance. This will not only make it possible to receive foreign exchange gains, but the exchange gains will also offset interest on the financing loan; the loan interest rate for trade financing will be much lower than the renminbi loan interest rate. This can help to solve the financing difficulties of enterprises, but also avoid exchange rate risk. It is relatively simple to avoid exchange rate risk when the renminbi is revalued. Using in advance to 
collect foreign exchange, utilizing foreign currency liabilities, and low interest loans, it is an optional means of operation for exporters, and the operation method is relatively simple.

When the exchange rate of RMB is depreciated, enterprises should pay attention to the fact that trade finance is prone to foreign currency liabilities and may generate exchange losses. This will increase the risk of the enterprises. At this time, At this point, whether trade finance can be chosen must be calculated. The situations faced by different electromechanical enterprises are different. In the case of a certain difference in the financing costs of RMB and foreign currency, the required exchange rate ratio is not the same. However, the principle is basically the same. Each electromechanical enterprise can carry out correlative derivation according to its own situation. Trade finance is a method of avoiding exchange rate risk that can be used in both the rise and fall of the RMB, and the effect of controlling exchange rate risk is relatively good.

2) Mechanical and electrical enterprises speed up the adjustment of their own product structure and increase the added value of products and technological innovation: Under the new international economic situation, the cost advantage of manufacturing in China is weakening. China's electromechanical enterprises must make full use of other advantages, such as increasing the added value of products technology and improving customer service quality and product quality. Mechanical and electrical enterprises should first analyze the advantages and disadvantages of their products, and formulate their future development direction. Put their backward products on the elimination list. At the same time, enterprises should look for ways to upgrade their technologies, such as enhancing their R\&D capabilities and learning from other enterprises' advanced technologies. In the production process, enterprises should increase the added value of their products and efficient use of existing material resources.

Electromechanical enterprises should focus on brand awareness, quality awareness, and transform from foundry production into a brand of self - owned enterprise. At the same time, the enterprises should have a Crisis consciousness. In the face of fluctuations in the RMB exchange rate, the negative impact that may bring to the company will be minimized. As of 2013, the number of large-scale electromechanical enterprises in China has reached 111,164, indicating that the market for electromechanical products is highly competitive. Therefore, electromechanical enterprises need to strive to improve quality of products and strive to win by quality. China is still dominated by low-end links in the global machinery and electronics industry division, Led to too many vicious price competitions. In order to enhance the competitive advantage of China's mechanical and electrical products, mechanical, electrical enterprises should pay attention to product quality and service quality while improving technological innovation, and Strive for more benign and effective competition.

\section{REFERENCES}

[1] He Xiuqiang. The Effect of RMB Real Effective Exchange Rate on Total Export Volume and Export Commodity Structure: A Study Based on Zhejiang Province Data [D]. Zhejiang University. 2012.5.

[2] Wang Yalin. The effect of the real effective exchange rate after China's accession to WTO on the export structure of electromechanical products in China[D]. Academic Papers and Comparative Library.2015.5.25.

[3] Zhang Dechao. A study on the choice of exchange rate risk aversion model for export enterprises. Academic papers and comparative database[D].2015.04.12.

[4] Mou Dan. The effect of real effective exchange rate of RMB on China's export structure. Southwestern University of Finance and Economics[D].2013.3.

[5] Lv Shufang. Empirical analysis of the impact of RMB exchange rate changes on China's export trade [J]. Economic issues. 2015(3).

[6] Wang Yaqi, Dai Mi, Xu Jianwei. Exchange rate, product quality and export price [J]. World Economy. 2015 (5).

[7] Deng Xiaohua, Li Zhanfeng.Research on the Impact of Exchange Rate Changes on China's Export Commodity Trade Structure[J].Technology and Economy of Quantitative Economy.2014(8).

[8] Zou Hongyuan, Luo Dawei. The Effect of RMB byl Industry and Effective Exchange Rate on the Export Volume of Various Industries in China[J]. Journal of Quantitative Economics and Technology Economics. 2014(11).

[9] Li Xianfeng, Huang Changli. The Impact of RMB Real Effective Exchange Rate on Export after the New Exchange Reform[J]: 2005Q32013Q3*. Macroeconomic Research. 2014(4).

[10] Wu Yulan. Empirical research on the effect of real effective exchange rate of RMB on China's processing trade[J]. Heilongjiang Foreign Trade and Economic Cooperation. 2008(2).

[11] Xu Wei, Sun Jun. The Effect of RMB Real Effective Exchange Rate on the Total Import and Export of China[J].International Trade Issues.2008(3).

[12] Zhou Ya (Tutor: Yu Bin). Research on the Relevance of Exchange Rate Changes to Foreign Trade Exports in Wenzhou[J]. Journal of Zhejiang University of Technology. 2013.12.01.

[13] Zhang Xian (Tutor: Deng Chao) Empirical Study on the Effect of RMB Exchange Rate Movement on Hunan Economy[D]. Master thesis of Central South University. 2007.06.30.

[14] Yin Lin (Instructor: Liu Ya). Evaluation of Exchange Rate Regime Selection in Emerging Market Countries [D]. Ph. D. Thesis, University of International Business and Economics. 2016.05.01.

[15] Yu Xin. Research on the measurement and management of foreign exchange risk in enterprises Taking China's banking industry as an example[D]. Joint Comparative Library Academic Papers .2015.10.09.

[16] Han Boyin. Zhang Shangxue. RMB exchange rate reform and China's economic development strategy [J]. Ecological Economy. 2006.05.30.

[17] Zhang Na (Advisor: Zhang Jian). Research on the Influencing Factors of RMB Exchange Rate System[D]. Master thesis of Jiangsu University. 2008.11.01.

[18] Peng Juan (Tutor: Yang Shenggang). The Effect of Exchange Rate System Reform on the Efficiency of China's Foreign Exchange Market [D]. Master thesis of Hunan University. 2011.04.01.

[19] Liu Xinwei. Trade frictions have caused the electromechanical industry to be "injured" and it is urgent to increase early warning. [J]. Chinese Foreign Trade. 2017.03.15.

[20] Yao Jinhua. Research on China's export competitiveness of mechanical and electrical products and its influencing factors[D]. Lanzhou University of Finance and Economics.2015.6.10.

[21] Li Zhenqiang; Zhang Ting. An empirical analysis of the relation between RMB exchange rate changes and import and export trade based on VAR model. 《Journal of Hunan University of Arts and Science(Science and Technology)》2015-04

[22] Topic 13 (Influence of Exchange Rate Fluctuations). College Students Examination Network. 